\title{
Occurrence of Microplastic in surface water of Jatiluhur Reservoir
}

\author{
Attar Hikmahtiar Ramadan $^{1}$ and Emenda Sembiring ${ }^{1 *}$ \\ ${ }^{1}$ Environmental Engineering Study Programme, Institut Teknologi Bandung Jl. Ganesa No.10, Bandung, Indonesia. 40132
}

\begin{abstract}
Microplastic is generally defined as synthetic polymers which size less than $5 \mathrm{~mm}$. Based on the latest research, microplastics pollutions have many impacts on the environment and human. Jatiluhur, as one of the biggest freshwater reservoir in Indonesia, has potential to be polluted by microplastics because the water source of this reservoir streamed from Citarum watershed. Citarum River is one of the most polluted river in Indonesia. To find the occurrence of microplastics and to facilitate future policies in order to overcome microplastic pollution which occurs in Jatiluhur Reservoir, a study of microplastic abundance is conducted. Primary data is obtained by using the volume reduced sampling method. Manta trawl is pulled beside a boat for 5-15 minutes for each sample and flow meter installed onto the mouth of manta trawl to determine the towing distance in surface water. Microplastic abundance in surface water presented in the form of microplastics amounts per unit surface area. Furthermore, microplastic characteristics analyzed with visual analysis, particle density analysis, and polymer analysis using FTIR. Based on seven sampling locations, microplastics have found in Jatiluhur Reservoir ranging from $0.71 \times 10^{4}-4.59 \times 10^{5}$ particles $/ \mathrm{km}^{2}$. The most type of microplastic found is fragmented polyethylene.
\end{abstract}

\section{Background}

Indonesia is one of the countries that have a high percentage of mismanaged plastics waste [1]. Mismanaged waste has a high potential to become microplastics. Microplastic is generally defined as a synthetic polymer under $5 \mathrm{~mm}$ [2]. Based on the process of forming, microplastic can be divided into two types, the first is primary microplastic, which is plastic that does have a micro size and is usually found in cleaning and cosmetic products [3]. The second source is secondary microplastic formed from plastics that already exists in the environment and it fragmented into a smaller plastics and become the microplastics [4].

Microplastic abundance found in many areas from freshwater to the pole areas [5], but the data of microplastic research in the freshwater, especially in lake and reservoir is limited. The latest research found the occurrence of microplastics in Three Gorges Reservoir [6] and Taihu Lake, China [7].

In general, potential sources of microplastics in freshwater ecosystem include wastewater treatment plants (WWTPs), beach litter, fishery, cargo shipping, and harbors [14]. Jatiluhur reservoir is one of the biggest reservoirs in Indonesia, and this reservoir has potential to be polluted by microplastics because the water of this reservoir is streamed from Citarum River, which has polluted by microplastic. Latest research told that microplastics has polluted a segment of Citarum River [8]. Furthermore, this river also has a long history of pollution, and even Citarum has been named as the top ten toxic threats in the world in 2013 [9] because of the high pollution and the enormous impact of pollution to the population around the Citarum River.

Jatiluhur Reservoir also has the enormous fisheries industries, these industries is using fishing net made from the plastics, if this net degraded and fragmented, it can be another source of microplastis. Moreover, in the upstream of Jatiuhur, there are two other Reservoirs (Cirata and Saguling), the activities in these reservoir also have potential to contribute the source of microplastics.

\section{Methodology}

\subsection{Sampling location}

This study conducted in Jatiluhur Reservoir, Purwakarta, West Java.

Sampling point in Jatiluhur Reservoir is determined based on purposive sampling. Sampling points is divided into 7 location, including discharge area, middle area, and outfall of Jatiluhur Reservoir. Location 1 and 2 is the inlet stream of Reservoir and location 6 is the outfall of Reservoir. The reason in determining the sampling locations in 3 different segments is to investigate the abundance of microplastics in each segment. Sampling location is presented at Fig 1 and Table 1.

" Corresponding author: endasembiring@yahoo.com 


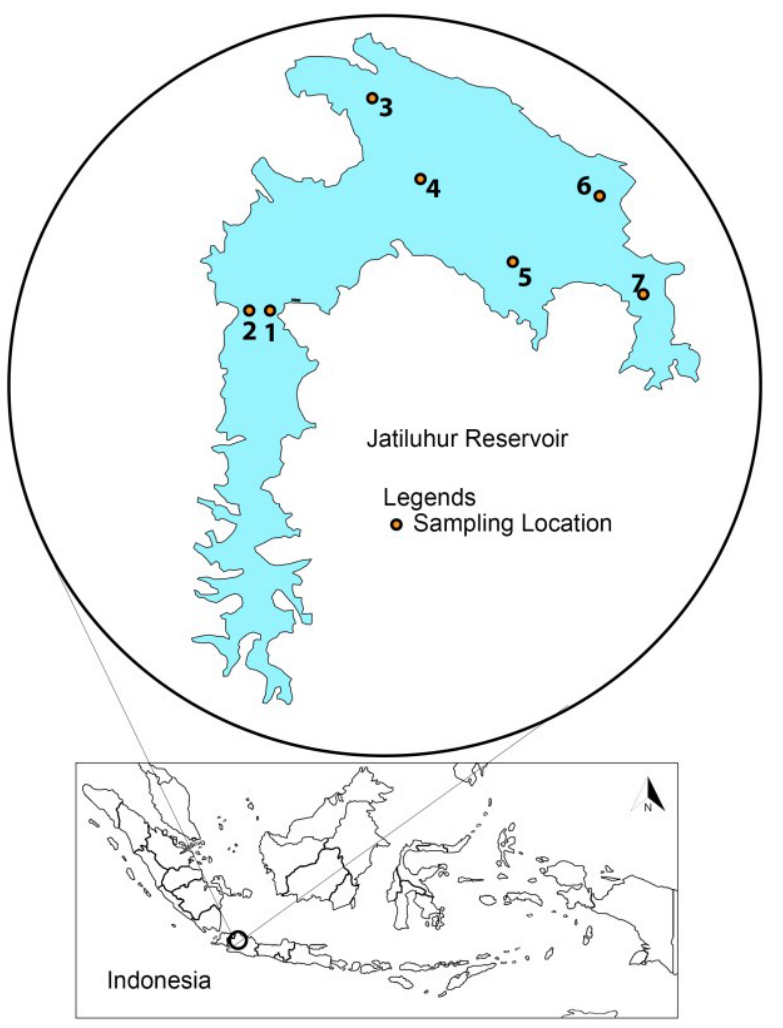

Fig 1. Sampling Location

Table 1. Coordinate of Sampling Locations

\begin{tabular}{|c|c|c|}
\hline Location & Longitude & Latitude \\
\hline 1 & 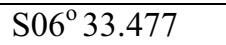 & $\mathrm{E} 107^{\circ} 18.235$ \\
\hline 2 & $\mathrm{~S}^{\circ} 6^{\circ} 33.432$ & $\mathrm{E} 107^{\circ} 17.855$ \\
\hline 3 & $\mathrm{~S}^{\circ} 6^{\circ} 30.559$ & $\mathrm{E} 107^{\circ} 20.532$ \\
\hline 4 & $\mathrm{~S} 06^{\circ} 31.782$ & $\mathrm{E} 107^{\circ} 20.837$ \\
\hline 5 & $\mathrm{~S}^{\circ} 6^{\circ} 32.652$ & $\mathrm{E} 107^{\circ} 22.397$ \\
\hline 6 & $\mathrm{~S}_{0} 6^{\circ} 31.723$ & $\mathrm{E} 107^{\circ} 23.267$ \\
\hline 7 & $\mathrm{~S} 06^{\circ} 32.527$ & $\mathrm{E} 107^{\circ} 23.119$ \\
\hline
\end{tabular}

\subsection{Sampling method}

Microplastic in the water surface was collected in May $2^{\text {nd }}, 2019$ using manta trawl with a rectangular shape, 30 $\mathrm{cm}$ high by $100 \mathrm{~cm}$ wide and $2.5 \mathrm{~m}$ long with 125 mesh size. Manta trawl was towed beside the boat with research boat and the speed was $5 \mathrm{~km} / \mathrm{h}$. Each sample was multiplying the towing distance with the width of the manta trawl to calculate the the area of sample. After microplastic took from surface water and preserved with formaldehyde $5 \%$, water sample was separated by a mesh according to the mesh used at manta trawl $(125 \mu \mathrm{m})$, extraction of microplastic begins with dried the sample by the oven with $60^{\circ} \mathrm{C}$ until it dries and then was destruction used Fenton Oxidation method where using $\mathrm{H}_{2} \mathrm{O}_{2}$ and $\mathrm{Fe}_{2}\left(\mathrm{SO}_{4}\right)_{3}$ to clean the organic matters in $75^{\circ} \mathrm{C}$ [10]. Particles that suspected as microplastics were picked and put to the Petri disk. The scheme of microplastic analysis is described in Fig 2.

Visualization with a microscope was conducted to determine the shape and size of microplastic. The photographic results from micropscope was analyzed with
ImageJ software to measure the size of microplastics. The type of plastic polymer determined using FT-IR. Wavelength setting of FTIR in this research ranging from $550-4000 \mathrm{~cm}^{-1}$, and the result were compared with reference spectrum of plastic polymer.

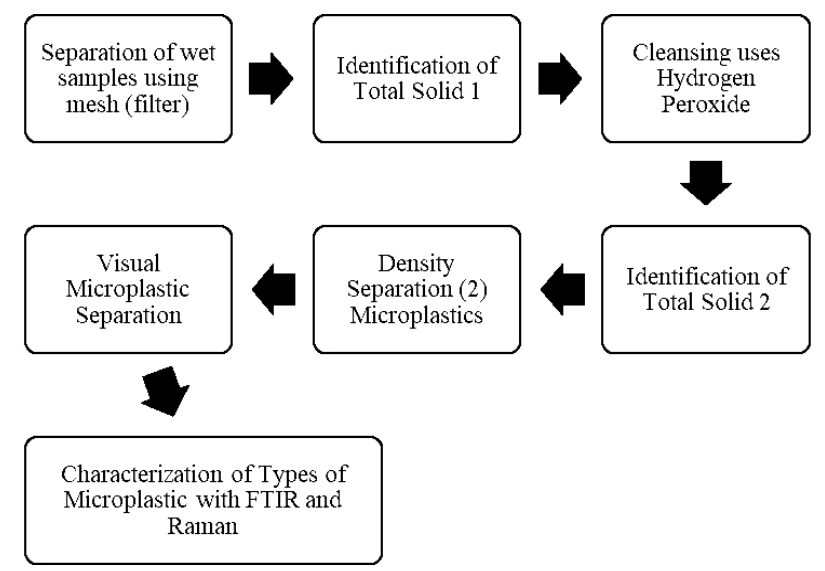

Fig 2. Microplastics Analysis Scheme [15]

\section{Result and discussion}

\subsection{Microplastic concentration in surface water}

Microplastics were found in all 7 sampling location in Jatiluhur Reservoir (Table 2). The abundance of microplastics ranged from $6.71 \times 10^{4}-4.59 \times 10^{5}$ particles $/ \mathrm{km}^{2}$. Observations on surface water showed that the average of microplastic concentration was $2.58 \times 10^{5}$ particles per $\mathrm{km}^{2}$.

Table 2.

Microplastic Concentration by the points

\begin{tabular}{cccc}
\hline $\begin{array}{c}\text { Location } \\
\text { (Points) }\end{array}$ & $\begin{array}{c}\text { Towing } \\
\text { Distance } \\
(\mathbf{m})\end{array}$ & $\begin{array}{c}\text { Amount of } \\
\text { Microplastic }\end{array}$ & $\begin{array}{c}\text { Particles per } \\
\mathbf{k m}^{\mathbf{2}} \text { ) }\end{array}$ \\
\hline $\mathbf{1}$ & 108.92 & 50 & $4.59 \times 10^{5}$ \\
$\mathbf{2}$ & 122.91 & 46 & $3.74 \times 10^{5}$ \\
$\mathbf{3}$ & 122.42 & 11 & $0.89 \times 10^{5}$ \\
$\mathbf{4}$ & 110.14 & 18 & $1.63 \times 10^{5}$ \\
$\mathbf{5}$ & 115.18 & 27 & $2.34 \times 10^{5}$ \\
$\mathbf{6}$ & 112.84 & 47 & $4.16 \times 10^{5}$ \\
$\mathbf{7}$ & 148.93 & 10 & $0.67 \times 10^{5}$ \\
\hline Average & & & $2.58 \times 10^{5}$ \\
\hline
\end{tabular}

Sampling location 1 and 2 in this research are the inlet and main stream of the Reservoir and the abundance of microplastics are higher than other locations. High abundance of microplastics in inlet/upstream of Jatiluhur may affected by the high human activities and microplastics transfer from reservoir in upstream, Saguling and Cirata. These two reservoir also have massive activities in fisheries e.g. fish net. In the sampling location near from the dam (location 6), microplastic abundance increase, because microplastics cannot pass the dam and accumulate behind the dam. Microplastic in surface water can only be removed by sedimentation process and settled in bottom of reservoir [11] or 
completely degraded, or accidentally ingested by aquatic organisms [6]

Table 3.

Comparison of microplastic concentration from Jatiluhur Reservoir with other areas

\begin{tabular}{cccc}
\hline $\begin{array}{c}\text { Study } \\
\text { Area }\end{array}$ & $\begin{array}{c}\text { MPs } \\
\text { Size }\end{array}$ & $\begin{array}{c}\text { MPs Abundance } \\
\left(\mathbf{1 0}^{\mathbf{5}} \text { counts } \mathbf{k m}^{-\mathbf{2}} \mathbf{)}\right.\end{array}$ & References \\
\hline $\begin{array}{c}\text { Lake } \\
\text { Huron }\end{array}$ & $>0.333$ & 0.028 & {$[12]$} \\
$\begin{array}{c}\text { Lake Erie } \\
\text { Three }\end{array}$ & $>0.333$ & 1.05 & {$[12]$} \\
$\begin{array}{c}\text { Gorges } \\
\text { Reservoir } \\
\text { Jatiluhur } \\
\text { Reservoir }\end{array}$ & $0.112-5$ & 84.65 & {$[6]$} \\
\hline
\end{tabular}

In comparison with other reservoir and lake, Jatiluhur is higher than Lake Huron and Lake Erie in North America, but lower than microplastics abundance in Three Gorges Reservoir, China. (Table 3). The difference of microplastic number in compared reservoir affected by many factors, such as the other reservoir in upstream of Jatiluhur, human activities, and massive fisheries activities in Jatiluhur reservoir.

\subsection{Microplastic size and shape}

Based on the size, microplastic found in Jatiluhur Reservoir classified into 3 size groups, from 100 - 500 $\mu \mathrm{m}, 501-1000 \mu \mathrm{m}$ and $1001-5000 \mu \mathrm{m}$. According the analysis, size between $1000 \mu \mathrm{m}$ to $5000 \mu \mathrm{m}$ were the most abundant than other sizes, accounting for $30.56-$ $74.07 \%$ of the total microplastics. Percentage of microplastics based on size is described in Table 4 .

Table 4.

Percentage of Microplastic divided by size

\begin{tabular}{cccc} 
Location & \multicolumn{3}{c}{ Size $(\boldsymbol{\mu m})$} \\
& $\mathbf{1 0 0 - 5 0 0}$ & $\mathbf{5 0 1 - 1 0 0 0}$ & $\mathbf{1 0 0 1}-\mathbf{5 0 0 0}$ \\
\hline $\mathbf{1}$ & $16.67 \%$ & $52.78 \%$ & $30.56 \%$ \\
$\mathbf{2}$ & $4.88 \%$ & $43.90 \%$ & $51.22 \%$ \\
$\mathbf{3}$ & $25.00 \%$ & $37.50 \%$ & $37.50 \%$ \\
$\mathbf{4}$ & $10.00 \%$ & $45.00 \%$ & $45.00 \%$ \\
$\mathbf{5}$ & $3.70 \%$ & $22.22 \%$ & $74.07 \%$ \\
$\mathbf{6}$ & $10.00 \%$ & $36.67 \%$ & $53.33 \%$ \\
$\mathbf{7}$ & $22.22 \%$ & $22.22 \%$ & $55.56 \%$ \\
Average & $13.21 \%$ & $37.18 \%$ & $49.61 \%$ \\
\hline
\end{tabular}

Most of microplastics shape that found in Jatiluhur are fragmented microplastics. Microplastics in Jatiluhur Reservoir are mostly formed by fragmented plastic from daily usage plastic products. Some of micropolastic were line shaped, probably fragmented from breakdown of fishing net of fisheries industry in this Reservoir. Typical examples of microplastics shape collected from Jatiluhur Reservoir presented in Fig. 3.
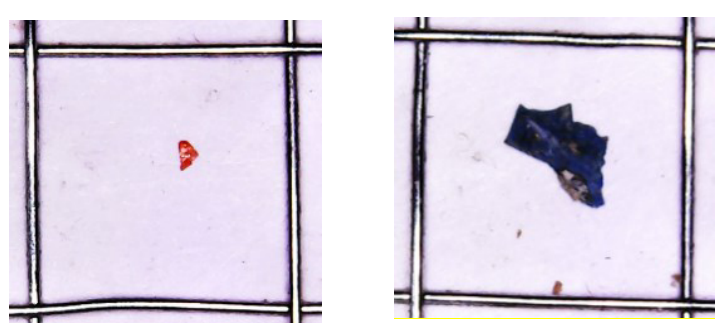

Fig 3. Microplastics Shape

\subsection{Microplastic polymer type}

The polymer types of microplastics were identified with FT-IR to be polyethylene (PE) and polypropylene (PP) (Fig. 4). Polyehylene is the most dominant microplastics in this reservoir, which account for $54.73 \%$ (Table . PP and $\mathrm{PE}$ mostly found in reservoir aand/or freshwater because the density is lower than water density, (PP and PP density $0.83-0.85 \mathrm{~g} \mathrm{~mL}^{-1}$; water density $1.0 \mathrm{~g} \mathrm{~mL}^{-1}$ ). Other types of plastics are likely to be settled in the bottom of reservoir because other microplastics density are higher than freshwater density [13]. Percentage of microplastic polymer type presented in Table 4 and Fig. 4.

Table 4.

Percentage of Microplastic divided by polymer type

\begin{tabular}{ccc}
\hline $\begin{array}{c}\text { Location } \\
\text { (Points) }\end{array}$ & $\begin{array}{c}\text { PE } \\
\text { (Polyethylene) }\end{array}$ & $\begin{array}{c}\text { PP } \\
\text { (Polyprophylene) }\end{array}$ \\
\hline $\mathbf{1}$ & $45.95 \%$ & $54.05 \%$ \\
$\mathbf{2}$ & $73.17 \%$ & $26.83 \%$ \\
$\mathbf{3}$ & $50.00 \%$ & $50.00 \%$ \\
$\mathbf{4}$ & $30.00 \%$ & $70.00 \%$ \\
$\mathbf{5}$ & $33.33 \%$ & $66.67 \%$ \\
$\mathbf{6}$ & $40.00 \%$ & $60.00 \%$ \\
$\mathbf{7}$ & $44.44 \%$ & $55.56 \%$ \\
Average & $45.27 \%$ & $54.73 \%$ \\
\hline
\end{tabular}

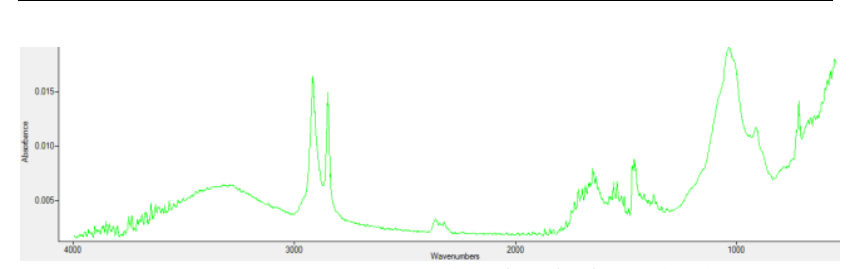

a. FTIR Spectra of Polyethylene (PE)

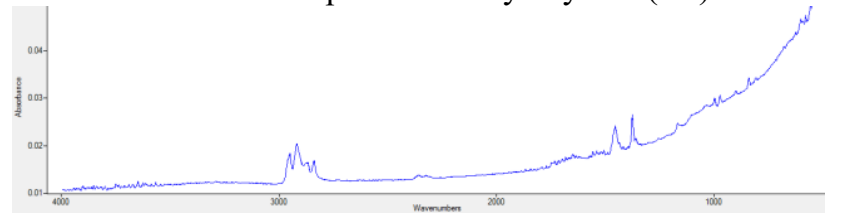

b. FTIR Spectra of Polypropylene (PP)

Fig 4. Microplastic Polymer Spectra in FTIR 


\section{Conclusion}

Occurrence of microplastics were observed in samples collected from Jatiluhur Reservoir. Typical microplastics shape in this area are fragmented microplastics sourced from breakdown of human activites plastics, and fisheries industries. The highest abundant is microplastic size ranging from 1000 to $5000 \mu \mathrm{m}$. Polymer type of microplastics in this Reservoir are PE and PP. Reservoir has potential to be the accumulation area of microplastics, because microplastics are trapped in reservoir.

\section{Acknowledgment}

This work was funded by P3MI ITB and Asia-Pacific Network for Investigation on Microplastics Pollution in Aquatic Envrionment In Selected Developing Countries From Southeast Asia.

\section{References}

1. Jambeck, J.R., Geyer, R., Wilcox, C., Siegler, T.R., Perryman, M., Andrady, A., Narayan, R., Law, K.L., Plastic waste inputs from land into the ocean. Science 347, 768-771. (2015)

2. Klein, S. Worch, E., and Knepper, T.P.,. Occurrence and Spatial Distribution of Micrpoplastics in River Shore Sediment of the Rhine-Main Area Germany. Environmental Science and Tech. 49. 6070-6076. (2015)

3. Cole, M., P. Lindeque, C. Halsband, and T. S. Galloway.. Microplastics as contaminants in the marine environment: A review. Marine Pollution Bulletin. (2011)

4. Browne M.A, Galloway T., and Thompson R. Microplastic--an emerging contaminant of potential concern. Integrated Environmental Assessment and Management. 3:559-561. (2007)

5. Isobe, A., Uchiyama-Matsumoto, K., Uchida, K., Tokai, T.,. Microplastics in the Southern Ocean. Marine Pollution Bulletin 114, 623-626. (2017)

6. Zhang, K., Gong., W., Lv, J., Xiong, X., and Wu, C., 2015. Accumulation of floating microplastics behind the Three Gorges Dam. Environmental Pollution 204 117-123. (2015)

7. Su, L., Xue,Y., Li, L., Yang, D., Kolandhasamy, P., Li, D., Huahong, S. Microplastics in Taihu Lake, China. Environmental Pollution 216. 711-719. (2016)

8. Alam, F.C., Sembiring, E., Muntalif, B.S., Suendo, V., Microplastic distribution in surface water and sediment river around slum and industrial area (case study: Ciwalengke River, Majalaya district, Indonesia). Chemosphere 224, 637-645. (2019)

9. Blacksmith Institute. The Worlds Worst 2013: The Top Ten Toxic Threats. Swiss. 2013

10. K. Duis and A. Coors. Microplastics in the aquatic and terrestrial environment: sources (with a specific focus on personal care products), fate and effects. Environ. Sci. Eur, 28(1), 1-25. (2016).
11. Van Cauwenberghe, L., Vanreusel, A., Mees, J., Janssen, C.R., Microplastic pollution in deep-sea sediments. Environ. Pollut. 182, 495-499. (2013)

12. Eriksen, M., Maximenko, N., Thiel, M., Cummins, A., Lattin, G., Wilson, S., Hafner, J., Zellers, A., Rifman, S.,. Plastic pollution in the South Pacific Subtropical Gyre. Mar. Pollut. Bull. 68, 71-76. (2013)

13. Sadri, S.S., Thompson, R.C. On the quantity and composition of floating plastic debris entering and leaving the Tamar Estuary, Southwest England. Mar. Pollut. Bull. 81, 55-60. (2014)

14. Wagner, M., Scherer, C., Alvarez Munoz., D., Brennholt, N., Microplastics in freshwater ecosystems: what we know and what we need to know. Environmental Sciences Europe, 26:12. (2014)

15. Eriksen, M. Max, L. Tim, K. Louis, C. Abigail, A. Laurent, L. Heather, R. Barent, R. Nicolas, C. O. Valeria, H. R. Erika, M. Carolynn, B. Anna, C. Martin, T. Microplastic sampling with AVANI trawl compared to two neuston trawls in the Bay of Bengal and South Pacific. Environmental pollution. (2017) 